\title{
Territorial Life Cycle Sustainability Assessment
}

3 (T-LCSA) of Sassuolo Industrial District (Italy) \\ Davide Settembre-Blundo ${ }^{1,2^{*}}$, Fernando E .García-Muiña ${ }^{2}$, Martina Pinii ${ }^{3}$, Lucrezia Volpi ${ }^{3}$, \\ Cristina Siligardi ${ }^{4}$ and Anna Maria Ferrari ${ }^{3}$ \\ 1 Gruppo Ceramiche Gresmalt, Sassuolo (Italy); davide.settembre@gresmalt.it \\ 2 Department of business administration (ADO), applied economics II and fundaments of economic \\ analysis, Rey-Juan-Carlos University, Madrid (Spain); \\ 3 Department of sciences and methods for engineering, University of Modena and Reggio, Emilia, Reggio \\ Emilia (Italy); \\ 4 Department of engineering "Enzo Ferrari", University of Modena and Reggio, Emilia, Modena (Italy) \\ * Correspondence: davide.settembre@gresmalt.it; Tel.: +39-0536-867-011
}

Abstract: One of the biggest challenges for European industry is to introduce sustainability principles into business models. This is particularly important in raw material and energy intensive manufacturing sectors such as the ceramic industry. The present state of knowledge lacks a comprehensive operational tool for industry to support decision-making processes geared towards sustainability. In the ceramic sector, the economic and social dimensions of the product and processes have not yet been given sufficient importance. Moreover, the traditional research on industrial districts lacks an analysis of the relations between firms and the territory with a view to sustainability. Finally, the attention of scholars in the field of economic and social sustainability, has not yet turned to the analysis of the Sassuolo district. Therefore, in this paper we define the Territorial Life Cycle Sustainability Assessment (T-LCSA), a method that can be a suitable tool to fill this gap, because through a mathematical model it is possible to obtain the information useful for decision makers to integrate the principles of sustainability both at the microeconomic level in enterprises, and at the meso-economic level for the definition of economic policies and territorial governance. Environmental and socio-economic analysis was performed from the extraction of raw materials to the packaging of the product on different product categories manufactured by the Italian ceramic industries of the Sassuolo district (northern Italy). For the first time the T-LCSA model, usually applied to unitary processes, is extended to the economic and industrial activities of the entire district, extending the prospect of investigation from the enterprise and its value chain to the integrated network of district enterprises.

Keywords: Sustainability; Territorial Life Cycle Sustainability Assessment (T-LCSA); Sassuolo Industrial District; Italian Ceramic Industry; Meso-economic level; Interpretative Method

\section{Introduction}

The challenge of sustainable development embraces both environmental aspects and issues of social and economic sustainability. Sustainable development means meeting the needs of present generations without jeopardizing the rights and opportunities of future generations, in accordance with principles of intra- and inter-generational equity (I would include here reference to UN Report of the World Commission on Environment and Development). The introduction of rules for safeguarding the environment and tools for monitoring company activities are important not only for protecting consumers and for defending principles of civilization but should also be seen as an 
important opportunity for companies that are striving to produce high-quality products. Accordingly, this capacity can be considered a strategic factor with great impact on competitive advantage building. Above and beyond short-term economic expediencies, companies are historic players whose actions influence the social life of the surrounding community. In addition, such community will evaluate firms' actions and behaviors according to the impacts they may provoke. Following the Institutional Theory (North, 1990; Scott, 1995), the consequences of entrepreneurial decisions are not limited to the company itself but extend to the various spheres of social life and affect the various economic and social parties and territories which are no longer neutral places. Therefore, as long as firms' impacts do not fit norms, values or game rules of the society, companies will be poorer evaluated.

This paper will conceptually develop the theme of relationships and interdependencies between companies organized in industrial districts (ID) and the territories in which they operate, and empirically will determine the environmental, economic and social impact of the main products of the ceramic district of Sassuolo in Italy, using the Life Cycle Sustainability Assessment (LCSA) structure with a territorial extension that we have defined as T-LCSA, what supposes a great contribution to the current literature.

\section{Theoretical framework and research aims}

\subsection{Environment and economic activity}

Economic activity, like all human activity, takes place within the natural environment. The economic system and the natural environment are therefore interdependent, which determines both the way in which the economic system affects the environment and the limits that the environment places on the evolution and expansion of the economic system [1]. The environmental limits that the economic system must consider are established by the laws of thermodynamics. The first law of thermodynamics is presented first in the form of the law of the conservation of matter: matter can neither be increased nor destroyed but only transformed [2]. The material flows from the environment to the economic system are the same as the flows that return from the economic system to the environment; the economic process can only transform the material extracted from the environment to eventually return the same material to the environment in the form of waste [3].

The processes of transformation of matter that take place in the economic system imply the use of energy, defined as the "capacity to do work". The first law of thermodynamics states that energy, like matter, can neither be created nor destroyed; energy can only be transformed, converted from one form to another [4]. This energy conversion has an important effect, highlighted by the second law of thermodynamics. This law states that in every energetic transformation a part of the energy is dispersed in a form that can no longer be used to perform further work [5]. The environment is an essential resource base for the functioning of the economic system. The scarcity of resources that is the fact that they are useful and at the same time available in limited quantities compared to the request, is the condition for the talk of economic resources [6].

If environmental resource activity is over-exploited beyond regeneration or assimilation capacity, environmental resources tend to run out and the ability of the environment to provide its services to the economy in the future is compromised. This creates a conflict between exploitation and conservation of the environment which is economically relevant as the environment performs important economic functions not only because the flows of services it offers are exploited, but also because there is an interest in the conservation of the stocks of goods it contains [7]. When environmental exploitation goes beyond the natural capacities of regeneration and assimilation, it is an alternative use of non-environmental economic resources (such as capital and labor) that goes against the objective of conservation. In this case, the exploitation and preservation of the environment become alternative purposes of resource allocation [8].

The essence of the concept of sustainable development is that the exploitation of environmental resources should be contained within the limits of regeneration capacity so that the stock of these resources is not depleted. If the stock of environmental resources is to remain constant in the long 
term, the exploitation flow of these resources must also be kept constant within the limits of their natural regeneration capacity [9]. But the only way in which the flow of use of environmental resources can remain constant in the presence of a continuous growth of the domestic gross product of an economy is that the flow of use of the environment per unit of gross domestic product is continuously reduced over time [10]. This also requires a profound structural modification of production processes. For this reason, economic growth to be sustainable must be based more and more on the material recycling [11], on a non-dissipative form of energy use and on an increasing weight of the intangible production component in the gross domestic product [12].

The most recent strategic documents of the European Union and the relative EU policies aim at combining competitiveness of member countries' enterprises and economies, social cohesion and sustainable development [13]. Further intergovernmental programmes promote the same strategic objectives of economic, social and environmental sustainability [14]. These documents identify local authorities, businesses and civil society as the actors responsible for implementing the strategic objectives set, although the key role of local authorities as relevant players in the promotion and implementation of policies and governance tools for sustainable environmental, economic and social development is highlighted. About the role of companies in contributing to greater socio-economic and environmental sustainability, the European Union has recently promoted the approach and concept of Corporate Social Responsibility (CSR). This is a way of voluntary integration, beyond the legal obligations, by companies of the social and environmental implications in their commercial operations and in their relations with the various stakeholders [15]. In order to address environmental issues, adequate information and knowledge is needed to underpin the choice of the most effective actions. Moreover, knowledge must be effectively usable and meaningful. The purpose of this information should be to provide an overview of sustainability, to overcome a sectoral view of the issues and to focus as much as possible on key elements. Finally, the issues addressed should not be limited to strictly environmental issues but should also include social and economic concerns [16]. An appropriate indicator system based on the laws of thermodynamics can be used to assess the pressures that economic and social activities exert on the environment, the resulting changes in the state of the environment, the resulting impacts (e.g. on ecosystems, human health, resource availability) and the political and social responses to these impacts through improvement actions. Sustainability indicators should reflect the mutual links between the environmental, economic and social aspects of development [17]. The sustainability assessment may cover:

- territorial systems (cities, regions, states) [18], environmental components (the atmosphere, soil, water) [19] and, lastly, socio-economic components (economic sectors, population) [20];

- actions relating to development policies (in the fields of energy [21], transport [22], urban areas [23], the protection and valorization of ecosystems [24] and Cultural Heritage [25], actions aimed at social integration and cohesion).

\subsection{Environment and territory}

In Italy, the geographical concentration of supply chains (based on an integrated system of production, where the entire process is controlled and managed in close collaboration with the best local producers), has allowed many companies to share in the industrial risk linked to development in harmony with the local situation. The system of districts, in fact, has had the ability to create development by reducing the distortions of capitalist systems and enhancing the integration of the industrial reality with the social and environmental fabric [26]. Economic theory has long recognized that agglomeration economies are able to improve the productivity of enterprises and encourage processes of territorial concentration of productive activity in districts [27]. In the decade of the 1990s these ideas represented the starting point for numerous theoretical studies, which forcefully brought out the link between territory and economic development [28-32]. However, research has focused almost exclusively on the benefits of economic development without considering the social costs involved. Today, in economic analysis, space ceases to be considered only a source of cost for businesses, and increasingly assumes the role of a favourable (or unfavourable) environment, 
creating "external economies" (or external diseconomies) [33]. Space becomes the meeting point between the actors of development, where forms of cooperation among enterprises are organized, where the social division of labour is decided; it is, in short, the meeting point between market forces and forms of social regulation [34].

Industrial districts (ID) are the structures where the interaction between territories and companies in the supply chain is best observed [35]. The analysis of the production organization of the industrial district and the factors that underlie it, allows us to shed light on new variables that acquire a significant importance in the location and investment decisions of economic operators, and that therefore influence the processes of transformation of the local economy [36]. The development process acquires definitively its character of "social process" and no longer only a technical process. The territory becomes, therefore, an active factor in the development process as it includes all those factors (historical, cultural, anthropological, environmental and social) that are at the basis of specific models of production organization, the continuous interaction between economic and social actors and, therefore, the processes of economic and social transformation [37]. However, in the analysis of industrial districts, the relationship between companies and their local context has long lacked a fundamental dimension in the logic of sustainability: that of environmental protection, that is, the link that exists between productive activities and pollution phenomena related to them. This is inconsistent with the growing importance of sustainable development principles in business strategies and public decision makers' agendas. Only recently there has been a growing interest (both theoretically and empirically) in sustainability as a driver of growth in industrial districts [38-40]. Given the importance of the socio-territorial context to district businesses, it is inevitable that the issue of environmental sustainability will also become crucial from the point of view of competitive development [41]. A local district system can be seen as a network of locally concentrated enterprises whose stability derives from a dynamic yet balanced relationship with the community and the networks of interaction that characterize individual enterprises [42]. This balance is dynamic because even in local systems it is possible to highlight the presence of a life cycle whose trend follows that of the product, the greater the production specialization of a local system. This is the case of the Sassuolo ceramic district located in the provinces of Modena and Reggio Emilia in Italy, analyzed in this paper [43]. The dynamism of this balance can favour, both from a theoretical and managerial point of view, the adoption of a life-cycle methodological approach, to explain the dynamics of some of the most famous district systems and to describe the prevailing modes of interaction among economic operators [44-48]. However, the adoption of a life-cycle perspective requires that the main social actors do not limit their responsibility to the stages of the supply chain that they directly control but would constitute the prerequisite for a solid sustainability assessment, in order to identify opportunities for reducing environmental impact, industrial costs and, as a consequence, greater efficiency in the use of resources $[49,50]$.

\subsection{Life-cycle paradigm from a territorial approach}

The implementation of sustainability policies requires the development of increasingly refined quantitative and qualitative tools for analyzing the environmental, economic and social impacts, the Triple Bottom Line (TBL) associated with collective and individual choices, both with more limited effects and with more complex medium and long-term implications [51]. Life Cycle Sustainability Assessment (LCSA) can be a suitable tool for this purpose, since through a mathematical model, it describes the set of business solutions that integrate into the decision-making processes supporting the development of a product (from its conception to its withdrawal from the market), both the view of the life cycle and the economic, environmental and social assessments necessary for the management of processes, with a total sharing of data related to it between the various company functions [52]. This quantitative analysis tool allows to implement the principles of sustainability in business practices through the integration of three different impact assessment tools: Environmental Life Cycle Assessment (LCA) for the environmental dimension [53]; Life Cycle Costing (LCC) for the economic dimension [54]; and Social Life Cycle Assessment (S-LCA) for the social dimension [55]. 
194

195

196

197

198

199

200

201

202

203

204

205

206

207

208

209

210

211

212

213

214

215

216
The integration of the three impact assessment methods is expressed in Klöpffer's conceptual formula [56]:

(1) $\mathrm{LCSA}=\mathrm{LCA}+\mathrm{LCC}+\mathrm{S}-\mathrm{LCA}$

The life-cycle paradigm based on the three pillars of sustainability offers a systemic perspective for decision making [57]. The strategic choice between alternative options should be made by looking at the "pluses" and "minuses" that characterize a product, process or activity "from the cradle to the grave", reconciling, as far as possible, the environmental, economic and social concerns of economic operators within the supply chain and the territory [58]. Sustainability Analysis, as a tool to monitor a production process, or an integrated supply chain and to develop and valorize a territory, is a topic that is having growing interest in the literature [59]. To this end, the LCA guidelines have recently been adapted to carry out an environmental assessment of a territory. The expectations of this framework, called "Territorial LCA", are in line with the European Directive (2001/42/EC) on Strategic Environmental Assessment applied to spatial planning programmes, i.e. to provide an environmental reference basis and compare spatial planning scenarios [60]. However, there is still no empirical evidence in the literature of the integration of the territorial factor into the assessment of economic and social impact, since studies are limited to the environmental dimension. Integrating the territorial dimension in the impact assessment means moving the field of observation from the microeconomic level (the company and its processes and products) to the meso-economic level, then to the entire supply chain with its flows of materials, energy resources, semi-finished and finished products [61]. Mesoeconomic systems are dynamic, complex and open systems with dynamic elements that reflect the complexity of the ways in which macro-targets are achieved [62]. The purpose of their operation is to achieve maximum efficiency from the use of their resources and know-how. Their efficient network structure of interdependent microeconomic agents connected through a division of task, promotes the rational use of the available economic potential of the macro-system, balancing development and minimizing operational risks [63]. According to this definition, the concept of industrial district (ID) can be described as localized meso-economic systems, consisting of interconnected heterogeneous, but complementary, microeconomic agents and specific local institutions that determine the role of these agents and stimulate the innovative development of these systems [64].

\subsection{Aim and scope}

This work presents an empirical study conducted with the Territorial Life Cycle Sustainability Assessment (T-LCSA) approach for the analysis at mesoeconomic level of the environmental, economic and social performance of the Sassuolo ceramic district in Italy. The research integrates the elements of an evolutionary industrial approach, the life cycle one, with economic-environmental theories, which are interested in the process of forming organizations, their growth and evolution. Based on the literature analysis, for the first time an evaluation of the economic and social impact of the Italian ceramic industry is carried out, as well as for the first time the integrated approach of Territorial LCSA is applied. In fact, there are no published studies by LCC and/or S-LCA concerning the Sassuolo ceramic district. The only known study is the sectorial Environmental Product Declaration (EPD) based on an analysis of the environmental data of Italian ceramic tile manufacturers, promoted by the Italian ceramic industry association (Confindustria Ceramica) [65]. To fill this gap, we propose the following main objectives:

- Assessment of the environmental and socio-economic impacts associated with the entire production life cycle for different types of ceramic tiles located in the Sassuolo industrial district.

- Verification of the usefulness of T-LCSA as a tool to support decision-making processes from a sustainable supply chain management perspective. 


\section{Materials and Assumptions}

The Sassuolo industrial district is made up of a network of 79 companies that manufacture ceramic tiles, located in ten municipalities straddling the provinces of Modena and Reggio Emilia. During 2016, ceramic companies produced about 341 million square meters, equal to $82 \%$ of Italian production, with a turnover of 5.4 billion euros [66]. Of the ceramic companies that make up the district, six have a turnover of more than 200 million euro, nine have a turnover of between 200 and 100 million euro, and the rest are below 100 million euro. These data have been elaborated by consulting the financial statements of the firms of the district, filed with the local Chambers of Commerce.

Four main types of product are manufactured in the Sassuolo district:

- Porous double-fired wall tiles: the tiles are obtained by a process divided into two distinct phases: a first phase of firing of the support which is then glazed and then fired again to obtain the fusion of the glaze. Two different kilns are used. The product, mainly intended for wall coverings, is characterized by high porosity (greater than $10 \mathrm{wt} \%$ water absorption), brilliance of the glazes and definition of colours. This typology corresponds to $6 \%$ of the total production.

- Porous single-fired wall tiles (or "monoporosa"): The tiles are obtained through a technique that involves single firing of the product: both bisque and glaze are fired in a single process, only one kiln is used. The product is porous (greater than $7 \mathrm{wt} \%$ water absorption) with aesthetic effects of smoothness and brightness on the surface and it is suitable for indoor wall covering. This typology corresponds to $3 \%$ of the total production.

- Glazed porcelain stoneware: the tiles are the result of the sigle firing of the ceramic product that achieves a suitable vitrification state with a water absorption level lower than $0.5 \mathrm{wt} \%$ (frost-proof). The ceramic body is a neutral colour composition made from precious materials. The subsequent application of a top layer of glaze is added in order to obtain refined motion effect and graphic variety on the surface. Glazed porcelain stoneware floors are suitable for indoor areas thanks to their stain and chemical attack resistance, making the surface easy to clean and to maintain. This typology corresponds to $60 \%$ of the total production.

- Unglazed porcelain stoneware: the tiles are obtained by a single firing process at high temperatures thath transforms the raw materials into very compact tiles that are resistant to frost, chemical attack, have a high mechanical resistance and hygienic. Porcelain stoneware is available in various surface finishes. This typology corresponds to $31 \%$ of the total production.

The production of ceramic tiles requires large quantities of raw materials that can be schematically divided into at least four fundamental components:

- Clay raw materials: clays and kaolin which give sufficient plasticity to ensure good formability.

- Melting raw materials: such as feldspars, which produce the glass phases necessary to promote solid-solid sintering reactions.

- Inert raw materials: feldspar sand and sand which have the function of balancing the composition of ceramic bodies, also containing the cost, as these are the cheapest raw materials.

- Additives raw materials: calcite and/or dolomite used mainly in the production of porous types of, or in smaller quantities as promoters of eutectic to facilitate the melting of feldspars into porcelain stoneware.

Using this classification, it is essential to refer to the composition of the ceramic bodies from which the different types of tiles are obtained. To this end, 15 industrially spray-dried powders [67] of ceramic body, corresponding to the four main product categories of the Sassuolo district, were collected from the main ceramic companies of the district. Chemical analyses were carried out on these powders to determine their composition and establish a compositional range that defines each 
type of ceramic in a representative way (Table 1a). From the average chemical compositions, through a reverse engineering (RE) process [68], it was possible to reconstruct the formulation of a "medium" body, typical for each product category, using the main raw materials available on the market (Table $1 b)$.

\begin{tabular}{|c|c|c|c|c|c|c|c|c|c|}
\hline & $\begin{array}{c}\text { POROUS } \\
\text { DOUBLE-FIRED }\end{array}$ & $\begin{array}{c}\text { POROUS } \\
\text { SINGLE-FIRED }\end{array}$ & $\begin{array}{c}\text { CLAZED } \\
\text { PORCELAIN }\end{array}$ & $\begin{array}{l}\text { UNGLAZED } \\
\text { PORCELAIN }\end{array}$ & & $\begin{array}{l}\text { POROUS } \\
\text { DOUBLEF FIRED }\end{array}$ & $\begin{array}{c}\text { POROUS } \\
\text { SINGLE-FIRED }\end{array}$ & $\begin{array}{c}\text { CLAZED } \\
\text { PORCELAIN }\end{array}$ & $\begin{array}{l}\text { UNGLAZED } \\
\text { PORCELAIN }\end{array}$ \\
\hline $\mathrm{SiO}_{2}$ & $53 \div 57$ & $60 \div 65$ & $69 \div 72$ & $65 \div 68$ & Ukrainian ball clay & 24 & 26 & 24 & 25 \\
\hline $\mathrm{Al}_{2} \mathrm{O}_{3}$ & $13 \div 16$ & $15 \div 18$ & $17 \div 19$ & $18 \div 20$ & German ball Clay & 17 & 17 & 18 & 19 \\
\hline $\mathrm{Fe}_{2} \mathrm{O}_{3}$ & $0,5 \div 0,7$ & $0,5 \div 0,7$ & $0,6 \div 0,8$ & $0,4 \div 0,6$ & $\begin{array}{l}\text { Turkish Na-Feldspar } \\
\text { It tiliain Na K-Feldspar }\end{array}$ & 12 & 20 & 24 & 30 \\
\hline $\mathrm{TiO}_{2}$ & $0,5 \div 0,7$ & $0,5 \div 0,7$ & $0,5 \div 0,7$ & $0,3 \div 0,6$ & Italian K-Feldspar & 11 & 12 & & \\
\hline $\mathrm{MgO}$ & $0 \div 4$ & $0 \div 4$ & $0,2 \div 0,4$ & $0,2 \div 0,7$ & Italian Feldspar Sand & 16 & 15 & & 11,5 \\
\hline $\mathrm{CaO}$ & $5 \div 12$ & $4 \div 6$ & $0,2 \div 0,4$ & $0,3 \div 1,2$ & \begin{tabular}{|l} 
Italian Calcite \\
tilalian Dolomite
\end{tabular} & 20 & 10 & & 1.5 \\
\hline $\mathrm{Na}_{2} \mathrm{O}$ & $1 \div 1,5$ & $1,5 \div 2,5$ & $2,5 \div 4,0$ & $3,5 \div 4,5$ & 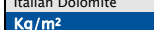 & $16 \div 18$ & $16 \div 18$ & $18 \div 22$ & $\frac{1,5}{21 \div 24}$ \\
\hline $\mathrm{K}_{2} \mathrm{O}$ & $2 \div 3$ & $2,5 \div 3,5$ & $2,5 \div 3,5$ & $2 \div 3,5$ & & & & & \\
\hline LOI & $11 \div 14$ & $7 \div 10$ & $3,3 \div 3,9$ & $3 \div 5$ & & & & & \\
\hline \multicolumn{5}{|c|}{ (a) } & \multicolumn{5}{|c|}{ (b) } \\
\hline
\end{tabular}

The compositions of the ceramic bodies shown in Table $1 \mathrm{~b}$ show that in all product categories, the import raw materials represent more than $50 \%$ of the total. This data is an indication of how vulnerable the district and its member companies are in their production processes, due to the criticality of the supply markets.

\subsection{Definition of industrial processes}

In order to configure a "standard" production plant that could be taken as a reference for the various product categories, it was based on the concept that the plants for the production of ceramic products all have the same plant characteristics, the main differences consist of the particularity of the machinery. The possible differences between the machines can be considered irrelevant for the analysis of aggregate average quantities as in this study. In this respect, it should be noted that the great differences between the various product categories do not lie in the machinery used, but in the different grinding and firing cycles and pressing loads, which have a clear impact on energy consumption per $\mathrm{m}^{2}$ of finished product. Table $2 \mathrm{a}$ shows the data relating to the average weight of the various product categories and the relative loss on ignition (L.O.I) from which it was possible to derive the firing efficiency and then determine the value of the surplus of raw material, expressed in $\mathrm{kg}$ per $\mathrm{m}^{2}$, to be added to the theoretical value. During the input phase of the dough creation data on the impact assessment software, the values in the fourth column were considered to determine the amount of raw material to be input.

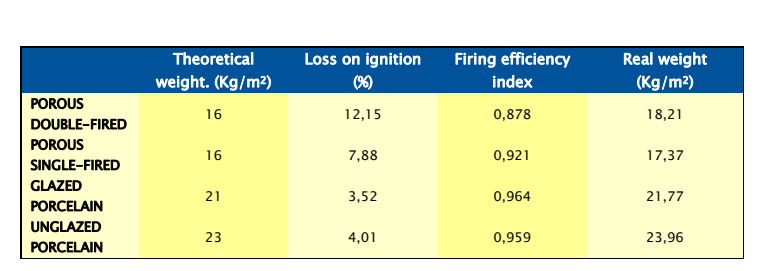

(a)

\begin{tabular}{|c|c|c|c|c|}
\hline & $\begin{array}{l}\text { Cost of electricity } \\
\left(\boldsymbol{\epsilon} / \mathrm{m}^{2}\right)\end{array}$ & $\begin{array}{l}\text { Consumption of } \\
\text { electrical energy } \\
\left(\mathrm{kWh} / \mathrm{m}^{2}\right)\end{array}$ & $\begin{array}{l}\text { Thermal energy } \\
\text { cost }\left(\boldsymbol{\ell} / \mathrm{m}^{2}\right)\end{array}$ & $\begin{array}{l}\text { Thermal energy } \\
\text { consumption } \\
\left(\mathrm{kcal} / \mathrm{m}^{2}\right)\end{array}$ \\
\hline $\begin{array}{l}\mid \text { POROUS } \\
\text { DOUBLE-FRED }\end{array}$ & 0,29 & 2,64 & 0,40 & 14.642 \\
\hline $\begin{array}{l}\text { POROUS } \\
\text { SINGLE-FIRED }\end{array}$ & 0,17 & 1,55 & 0,38 & 13.910 \\
\hline \begin{tabular}{|l} 
GALZED \\
PORCELAI
\end{tabular} & 0,30 & 2,73 & 0,58 & 21.232 \\
\hline \begin{tabular}{|l} 
UNGLLAZED \\
PORCELAIN
\end{tabular} & 0,44 & 4,00 & 0,72 & 26.357 \\
\hline
\end{tabular}

(b)

Table 2: (a) firing efficiency of the compositions studied and quantity of ceramic body per $\mathrm{m}^{2}$ needed for production; (b) Consumption of electricity and methane gas (expressed as thermal energy) per $\mathrm{m}^{2}$ of product.

\subsection{Energy consumption estimation}

For the quantification of average energy consumption, the data for 2016 was used. Table $2 b$ shows the cost of electricity (expressed in euro $/ \mathrm{m}^{2}$ ) and heat for each product category. When entering the data in the calculation software, it was decided to enter the average electricity consumption for each $\mathrm{m}^{2}$ of product; it was therefore considered appropriate to convert the unit of measurement in 
$\mathrm{kWh} / \mathrm{m}^{2}$. The average electricity consumption, expressed in $\mathrm{kWh} / \mathrm{m}^{2}$, has been calculated using a conversion factor that considers $0.11 € / \mathrm{kWh}$ as the cost of electricity for users of the order of at least $20 \mathrm{GWh} /$ year. The same procedure was adopted for quantifying the average thermal energy consumption (methane gas) per $\mathrm{m} 2$ of product. The total cost therefore amounts to 0.224 euro/ $\mathrm{Nm}^{3}$ of methane gas and dividing the cost per square meter by this value, the energy consumption expressed in $\mathrm{Nm}^{3} / \mathrm{m}^{2}$ was obtained.

\subsection{Air pollutant emissions}

For the calculation of emission factors of the main pollutants present in gaseous emissions deriving from production processes, reference was made to the data calculated based on the measurements made by ARPAE (Regional Agency for the Environment and Energy of EmiliaRomagna) [73]. For the bodies in which carbonates were introduced (Porous single-fired: $10 \%$ of calcite; Porous double-fired: $20 \%$ of calcite; Unglazed porcelain stoneware: $1.5 \%$ of dolomite and Glazed porcelain stoneware: $0.5 \%$ of calcite), $\mathrm{CO}_{2}$ emissions deriving from the decarbonization process had to be calculated. The reasoning followed to reach the $\mathrm{CO}_{2}$ emission value per $\mathrm{m}^{2}$ of product is based on molar ratios and on the approximation that all the Carbon released is fully bound to oxygen. Having calculated the $\mathrm{Kg}$ of calcite, $\mathrm{CaCO}_{3}$, and dolomite, $\mathrm{CaMg}\left(\mathrm{CO}_{3}\right)_{2}$, present in one $\mathrm{m}^{2}$ of product, and having their weights and molar ratios, $\mathrm{CO}_{2}$ emissions were calculated.

\subsection{Water consumption}

The ceramic tile industry has a relatively high-water requirement, associated with the various functions that water must perform (grinding of raw materials and glazes, cooling, washing of lines, etc.). A large proportion of the incoming water is, however, destined to be re-entered into the environment through gaseous emissions (evaporated water). While the use of water as a washing fluid generally corresponds to the production of waste water. Based on the data collected, it was established that average water consumption was $11 \mathrm{~kg} / \mathrm{m}^{2}$.

\subsection{Cost of raw materials}

Table 3a shows the average market prices of the main raw materials used in the manufacture of tiles, including the costs incurred for transport from the suppliers' mines to the Sassuolo district area. Based on the compositions shown in Table $1 b$, the cost of each ceramic body was obtained for all the product categories considered (Table $3 b$ ).

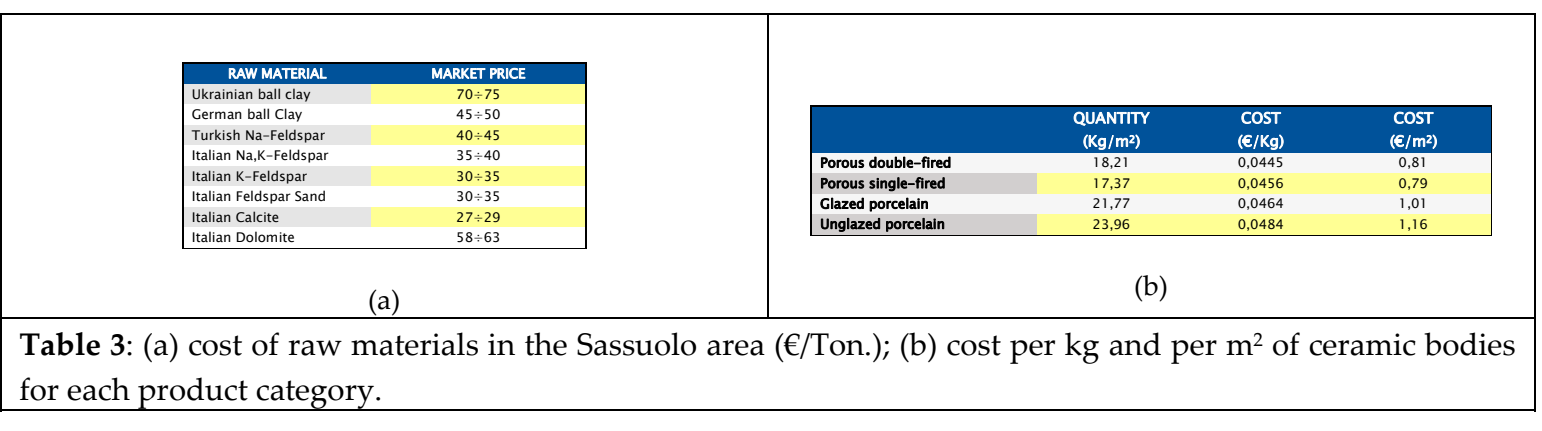

\subsection{Production costs}

The cost analysis was based on the "value chain" developed by Porter, which disaggregates a company according to its strategically relevant activities [74]. 


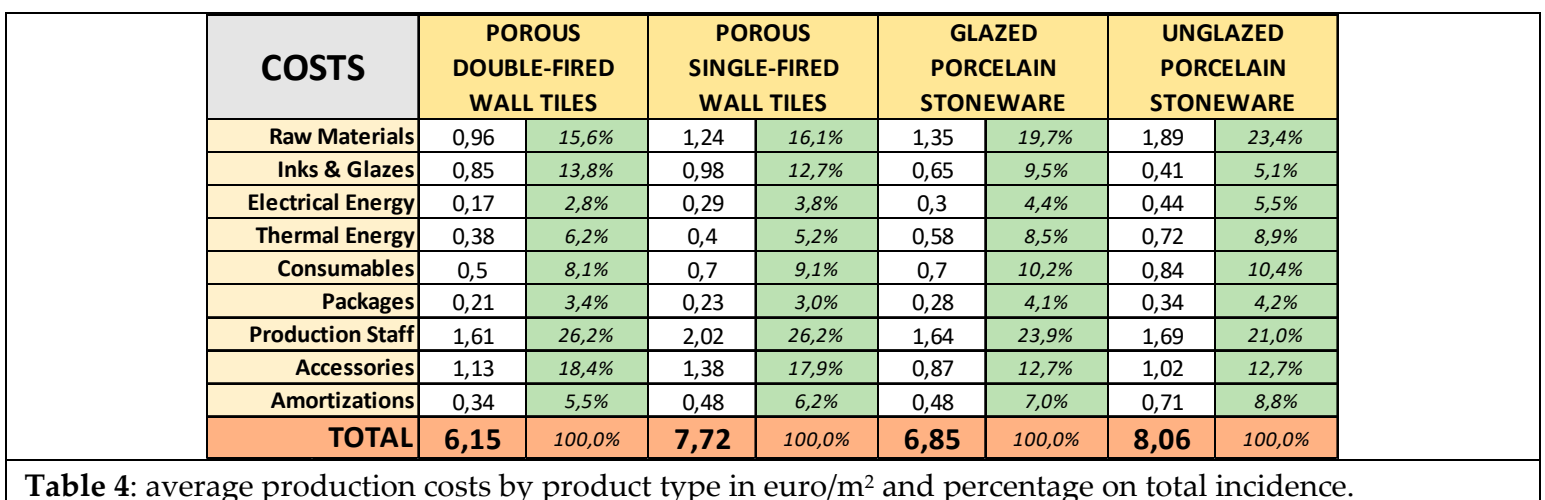

Table 4: average production costs by product type in euro $/ \mathrm{m}^{2}$ and percentage on total incidence.

Two areas have been identified: one closely linked to the transformation of raw materials into finished products, valued based on costs. The other one called "staff costs" is subdivided into average commercial costs and average general, administrative and financial costs. Charged according to the functional logic of "cost centers" [75]. A survey carried out recently by Confindustria Ceramica (Association of Italian Ceramic Producers) on the dynamics of costs has involved 60 production units concentrated for $89 \%$ in the district of Sassuolo and divided into the four types of this study. Employment of the sample companies accounts for $46 \%$ of the total number of employees in the sector. Just under $45 \%$, the weight of production. It is therefore a representative sample and the results are shown in Table 4.

\subsection{Social issues}

The collection of social data was carried out through the adoption of the Participatory Process [76] of social agents operating in the district. From the methodological point of view, the same procedure has been followed as that already used by the authors themselves for a study concerning the restoration of an architectural work of historical and artistic value [77]. As socioeconomic indicators relevant to ceramic production on Sassuolo District, the expectations of the main Stakeholder have been adopted.

\begin{tabular}{|c|c|c|}
\hline STAKEHOLDER CATEGORIES & STAKEHOLDER SUBCATEGORIES & STAKEHOLDER DETAILS \\
\hline \multirow{6}{*}{ 1.Human Resources } & \multirow{4}{*}{ 1.1 Staff Personnel } & 1.1.1 Blue-collar Workers \\
\hline & & 1.1.2 Employees \\
\hline & & 1.1.3 Managers \\
\hline & & 1.1.4 Top Management \\
\hline & \multirow{2}{*}{ 1.2 Trade Unions } & 1.2.1 Confederal Trade Unions \\
\hline & & 1.2.2 Independent Trade Unions \\
\hline \multirow{3}{*}{ 2.Local Community } & \multirow{3}{*}{ 2.1 Local Public Institutions } & 2.1.1 Regional Governments \\
\hline & & 2.1.2 Provincial Governments \\
\hline & & 2.1.3 Municipalities \\
\hline \multirow{13}{*}{ 3.Society } & \multirow{3}{*}{ 3.1 Private Business } & 3.1.1 Company's Shareholders \\
\hline & & 3.1.2 Association of Manufacturing and Service Companies \\
\hline & & 3.1.3 Chambers of Commerce \\
\hline & \multirow{4}{*}{ 3.2 Public and Private Organization } & 3.2.1 Regulatory Authorities \\
\hline & & 3.2.2 Research Community \\
\hline & & 3.2.3 National and International Public Institutions \\
\hline & & 3.2.4 Civil Society Organizations \\
\hline & \multirow{2}{*}{ 3.3 Environment } & 3.3.1 Natural Environment \\
\hline & & 3.3.2 Future Generations \\
\hline & \multirow{4}{*}{ 3.4 Media } & 3.4.1 Newspapers \\
\hline & & 3.4.2 Professional Magazines \\
\hline & & 3.4.3 TV and Radio \\
\hline & & 3.4.4 Internet \\
\hline \multirow{5}{*}{ 4.Consumers } & \multirow{3}{*}{ 4.1 Trade Channel Operators } & 4.1.1 Resellers \\
\hline & & 4.1.2 Trading Partners \\
\hline & & 4.1.3 Business Customers \\
\hline & \multirow{2}{*}{ 4.2 Final Consumer } & 4.2.1 Private Customers \\
\hline & & 4.2.2 Consumers Associations \\
\hline \multirow{3}{*}{ 5.Value Chain Actors } & 5.1 Suppliers & \begin{tabular}{|l} 
5.1.1 Large-Scale Suppliers \\
5.1.2 Small-Scale- Suppliers
\end{tabular} \\
\hline & 5.2 Partners & 5.2.1 Practitioners and Professionals \\
\hline & 5.3 Competitors & \begin{tabular}{|l|} 
5.3.1 Direct Competitors \\
5.3.2 Indirect Competitors \\
\end{tabular} \\
\hline
\end{tabular}

Table 5: stakeholder mapping involved in the ceramic production of Sassuolo District (Source: our elaboration based on the SETAC/UNEP guidelines and the AA1000 standard). 
The first step of the Participatory Approach consists of selecting stakeholders. For the operational identification of the Stakeholder we have used an adaptation of the tools contained in the guidelines of the AA1000 "Stakeholder Engagement Standard" (AA1000SES). These guidelines were published in 2015 and provide a framework for organizations to identify, respond and prioritize their sustainability challenges [78]. The AA1000 standard is a liability standard focused on ensuring the quality of social and ethical accounting, auditing and reporting [79]. In this way and in accordance with the SETAC/UNEP guidelines, we have identified the stakeholder involved in the ceramic production adopting the principles of Responsibility, Influence, Proximity, Dependency and Representation described in AA1000 standard. Table 5 shows the correspondences between the categories defined by the SETAC/UNEP guidelines and sub categories of stakeholder of Sassuolo District.

\section{Method and data processing}

The procedure we propose for the Territorial Life Cycle Sustainability Assessment (T-LCSA), provides for the integration between the three tools of impact assessment (LCA, LCC, S-LCA), so in accordance with ISO 14040, ISO 14044 and ISO 15686 standards we will adopt the same main phases for each dimension (environment, economy and society): goal and scope, inventory analysis, impact assessment and interpretation. We will also upscale the traditional LCSA to the ceramic district, considering the territorial component by processing data relating to the management of the entire supply chain.

\subsection{Goal and scope definition}

The objective of the study is to assess the environmental and socio-economic impact of ceramic production in the Sassuolo district.

\subsubsection{System Studied}

Ceramic tiles, produced by the companies belonging to the District of Sassuolo, which extends terriorially between the provinces of Modena and Reggio Emilia in Italy and includes the municipalities of Sassuolo, Fiorano Modenese, Formigine, Maranello, Castelvetro, Castellarano, Scandiano, Casalgrande, Viano and Rubiera.

\subsubsection{Function of the system}

For this study four types of medium ceramic products were identified and adopted, representing the entire district production: porous double-fired wall tiles, porous single-fired wall tiles, glazed porcelain stoneware and unglazed porcelain stoneware. The ceramic tiles under study are intended and applied for both floor and wall coverings, installed both in internal and external environments.

\subsubsection{Functional unit}

For the purpose of this study, the functional unit chosen, is $1 \mathrm{~m}^{2}$ of each of the selected product categories.

\subsubsection{System boundary}

In accordance with previous studies on a similar ceramic product [80], the system boundaries cover the entire life cycle of the system analyzed, in accordance with the LCA methodology (cradleto-grave). The analysis includes raw material extraction and utilization in green tile production; firing of the green tile to produce ceramic tiles; The production, maintenance and disposal of facilities as well as the environmental burdens related to the production of chemicals, additives, adhesives, packaging and other auxiliary materials are also included in the present study. Emissions into the air and water as well as the so lid waste produced in each step are all considered. The transportation of the solid waste to a treatment facility is also considered. In this study, we have also adopted the spatialization of each phase of the LCA [81], considering also the flows of raw materials and their 
impacts that come from other territories both in Italy (Tuscany, Piedmont, Sardinia) and abroad (Germany, Turkey and Ukraine).

\subsubsection{Data quality and impact assessment methodology}

Primary data concerning the raw materials extraction processes, were provided directly by the manufacturing companies, as were primary data on production processes of inks, glazes and pigments. Where the data have been missing, the study has been completed based on information obtained from the Ecoinvent database [82] that have been used to model the back-ground processes (land use, materials production, fuel and electricity production and transports). The analysis is conducted using the SimaPro 8.0.2 software and IMPACT 2002+ evaluation method to assess the environmental impacts

\subsection{Inventory analysis}

Life cycle inventory background data, costs including inputs and outputs in processes to produce ceramic tiles as well the emissions and social issues, have already been described in detail in paragraphs 3.

\section{Results and Discussion}

\subsection{LCA: Impact Assessment}

Table 6 shows the impact evaluation results for each of the four types of ceramic products and the total expressed by Weight Factor (Pt), while in the diagram of Figure 1 the same values are shown graphically. In general, the processes produce an impact due to $19,7 \%$ to the porous double firing wall tiles, $22,2 \%$ to porous single firing wall tiles, $25,7 \%$ to glazed porcelain stoneware and $32,3 \%$ to unglazed porcelain stoneware.

In order to estimate the environmental damage that ceramic production has on the district, a further calculation was made by weighting the impacts with the square meters produced for each type of product considered. In this way we have passed from the level of microeconomic analysis (which refers only to the functional unit of $1 \mathrm{~m}^{2}$ of ceramic tiles) to the level of meso-economic analysis which refers to the entire district. The results are shown in Figure 1a.

\begin{tabular}{|c|c|c|c|c|c|c|}
\hline \multicolumn{7}{|c|}{ LCA } \\
\hline DAMAGE CATEGORIES & IMPACT CATEGORIES & $\begin{array}{c}\text { POROUS } \\
\text { DOUBLE } \\
\text { FIRING WALL } \\
\text { TILES }\end{array}$ & $\begin{array}{c}\text { POROUS } \\
\text { SINGLE FIRING } \\
\text { WALL TILES }\end{array}$ & $\begin{array}{c}\text { GLAZED } \\
\text { PORCELAIN } \\
\text { STONEWARE }\end{array}$ & $\begin{array}{l}\text { UNGLAZED } \\
\text { PORCELAIN } \\
\text { STONEWARE }\end{array}$ & TOTAL \\
\hline \multirow{4}{*}{ HUMAN HEALTH } & Carcinogenic agents & $1,45 \mathrm{E}-05$ & $1,60 \mathrm{E}-05$ & $2,60 \mathrm{E}-05$ & $3,50 \mathrm{E}-05$ & \multirow{4}{*}{$3,22 \mathrm{E}-03$} \\
\hline & \begin{tabular}{|l|} 
Non-carcinogenic agents \\
\end{tabular} & $3,80 \mathrm{E}-05$ & $4,10 \mathrm{E}-05$ & $4,90 \mathrm{E}-05$ & $5,70 \mathrm{E}-05$ & \\
\hline & Respiratory inorganic & $6,10 \mathrm{E}-04$ & $7,10 \mathrm{E}-04$ & $7,10 \mathrm{E}-04$ & $9,10 \mathrm{E}-04$ & \\
\hline & Respiratory organic & $1,00 \mathrm{E}-06$ & $1,20 \mathrm{E}-06$ & $1,40 \mathrm{E}-06$ & $1,70 \mathrm{E}-06$ & \\
\hline & & & & & & \\
\hline \multirow{6}{*}{ ECOSYSTEM QUALITY } & Ozone depletion & $2,40 \mathrm{E}-07$ & $3,00 \mathrm{E}-07$ & $3,60 \mathrm{E}-07$ & $4,70 \mathrm{E}-07$ & \multirow{6}{*}{ 4,07E-04 } \\
\hline & Aquatic ecotoxicity & $6,50 \mathrm{E}-06$ & $1,00 \mathrm{E}-05$ & $8,30 \mathrm{E}-06$ & $1,10 \mathrm{E}-05$ & \\
\hline & Terrestrial ecotoxicity & $6,50 \mathrm{E}-05$ & $8,20 \mathrm{E}-05$ & $7,70 \mathrm{E}-05$ & $8,00 \mathrm{E}-05$ & \\
\hline & Aquatic acidification & $0,00 E+00$ & $0,00 E+00$ & $0,00 E+00$ & $0,00 E+00$ & \\
\hline & Soil acidification & $9,80 \mathrm{E}-06$ & $1,20 \mathrm{E}-05$ & $1,20 \mathrm{E}-05$ & $1,40 \mathrm{E}-05$ & \\
\hline & Land occupation & $3,60 \mathrm{E}-06$ & $4,90 \mathrm{E}-06$ & $4,20 \mathrm{E}-06$ & $5,30 \mathrm{E}-06$ & \\
\hline CLIMATE CHANGE & Global warming & $8,90 \mathrm{E}-04$ & $9,50 \mathrm{E}-04$ & $1,10 \mathrm{E}-03$ & $1,40 \mathrm{E}-03$ & $4,34 \mathrm{E}-03$ \\
\hline & & & & & & \\
\hline \multirow{4}{*}{ RESOURCES } & Nonrenewable energy & $8,10 \mathrm{E}-04$ & $9,20 \mathrm{E}-04$ & $1,20 \mathrm{E}-03$ & $1,50 \mathrm{E}-03$ & \multirow{2}{*}{$4,44 \mathrm{E}-03$} \\
\hline & Mineral extraction & $3,20 \mathrm{E}-06$ & $4,80 \mathrm{E}-06$ & $2,70 \mathrm{E}-06$ & $3,60 \mathrm{E}-06$ & \\
\hline & $\begin{array}{r}\text { TOTAL } \\
\end{array}$ & $2,45 \mathrm{E}-03$ & $2,75 \mathrm{E}-03$ & $3,19 \mathrm{E}-03$ & $4,02 \mathrm{E}-03$ & $1,24 \mathrm{E}-02$ \\
\hline & & $19,7 \%$ & $22,2 \%$ & $25,7 \%$ & $32,3 \%$ & \\
\hline
\end{tabular}

Table 6: association between impact and damage categories according to Impact 2002+ methodology and results of the LCA analysis for each product category detailed by each impact category and expressed in Pt.

The greatest impact for all products corresponds to the category of damage to human health. The detrimental effect on human health is mainly related to the NOx (nitrogen oxide) emissions associated with transportation of raw materials from the extraction sites to the factory sites at $(41,9 \%$ 
overall). Clearly the same NOx emissions affect climate changes ( $24,2 \%$ in total). Figure $1 \mathrm{~b}$ shows, in a comparative diagram, the results of the environmental impact of the production categories for the entire district in aggregate form.

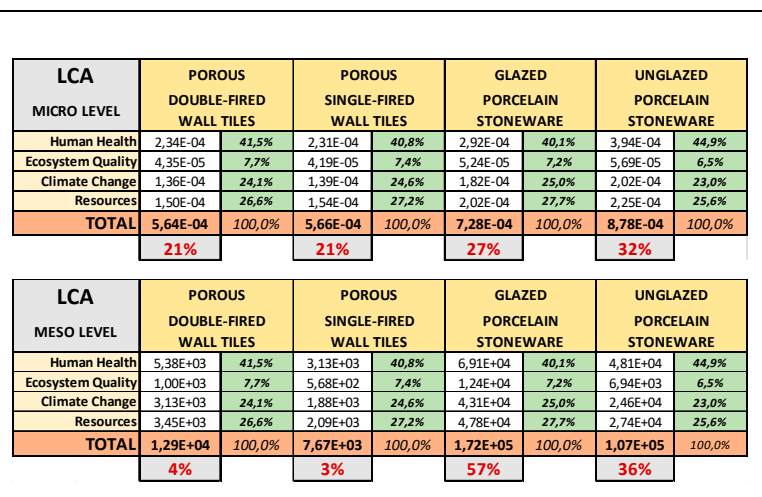

(a)

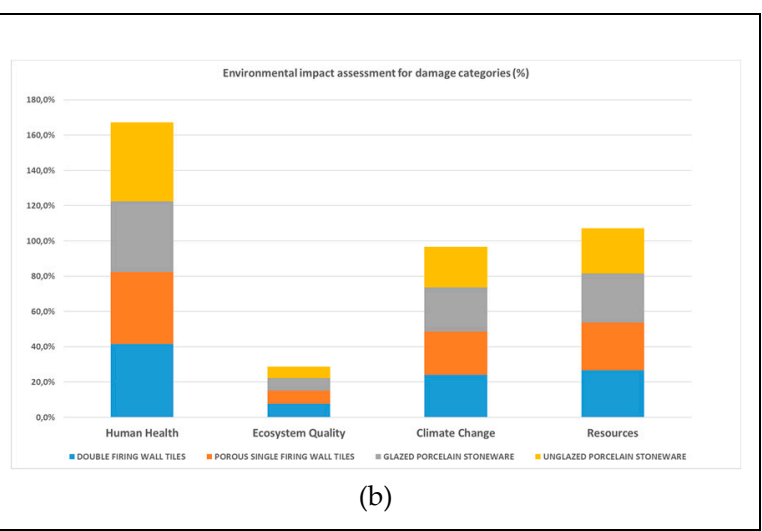

(b)

Figure 1: (a) impact of production in absolute value and expressed in \% for each category of damage at micro and meso level; (b) Environmental profile diagrams of the ceramic production process to the district by category of damages and expressed in $\%$.

\subsection{LCA: Results Interpretation}

The environmental impact analysis carried out at micro level, having as a reference $1 \mathrm{~m}^{2}$ of ceramic tiles for each product category, showed that the types with the most moderate impact are unglazed porcelain stoneware and glazed porcelain stoneware, while no significant variations were observed in the category of damage between the various typologies. Changing the perspective of observation and moving on to meso level, then to the district level considering production volumes, takes the effect of weighting volumes downwind and, of course, the product category most impacting is glazed porcelain stoneware.

\subsection{LCC: Inventory Costs}

Likewise, to the preceding LCA, all the relevant costs have been considered, with reference to the functional unit, for the four product categories already described above: porous double-fired wall tiles, porous single-fired wall tiles, glazed porcelain stoneware and unglazed porcelain stoneware (Paragraphs 3.5 and 3.6).

\subsection{LCC: Costs Assessment}

In an integrated process for the manufacturing of a product, the life cycle of costs is the sum of the costs attributable to the individual life cycle stages [83]:

$$
\text { LCC тот }=\text { Development Costs }+ \text { Utilization Costs }+ \text { Disposal Costs }
$$

To adapt the above conceptual formula (2) to the specific case under study, we propose this new empirical formula:

$$
\text { LCC тот }=\text { Production Costs }+ \text { Utilization Costs }+ \text { Externalities }
$$




\begin{tabular}{|c|c|c|c|c|c|}
\hline & LIFE CYCLE COSTING & $\begin{array}{c}\text { POROUS } \\
\text { DOUBLE-FIRED } \\
\text { WALL TILES }\end{array}$ & $\begin{array}{c}\text { POROUS } \\
\text { SINGLE-FIRED } \\
\text { WALL TILES }\end{array}$ & $\begin{array}{c}\text { GLAZED } \\
\text { PORCELAIN } \\
\text { STONEWARE }\end{array}$ & $\begin{array}{l}\text { UNGLAZED } \\
\text { PORCELAIN } \\
\text { STONEWARE }\end{array}$ \\
\hline & & PRODUC & TION COST & & \\
\hline & Production $\left(\mathrm{m}^{2}\right)$ & 22.978 .356 & 13.545 .628 & 236.734 .900 & 121.954 .343 \\
\hline & Production Costs ( $€ / \mathrm{m} 2)$ & 6,15 & 7,72 & 6,85 & 8,06 \\
\hline & & 141.316 .889 & 104.572 .248 & 1.621 .634 .065 & 982.952 .005 \\
\hline & TOTAL PRODUCTION COSTS & & 2.850. & 75.207 & \\
\hline & & UTILIZA & IION COST & & \\
\hline & Utilization Costs $(€ / \mathrm{m} 2)$ & 6,56 & 6,85 & 8,99 & 10,01 \\
\hline & 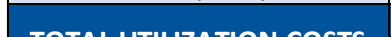 & 150.738 .015 & 92.787 .552 & 2.128 .010 .016 & 1.220 .762 .973 \\
\hline & IOIAL UIILIZA IION COSIS & & 3.592 .2 & 98.557 & \\
\hline & & EXTER & VALITIES & & \\
\hline & Human Health & 0,11 & 0,13 & 0,15 & 0,17 \\
\hline & Ecosystem Production Capacity & 0,11 & 0,14 & 0,14 & 0,19 \\
\hline & Abiotic Stock Resorurce & 0,54 & 0,83 & 0,41 & 0,50 \\
\hline & Biodiversity & 0,0014 & 0,0015 & 0,0018 & 0,0023 \\
\hline & TOTAL & 0,76 & 1,10 & 0,71 & 0,86 \\
\hline & TOTAI EYTEPNA ITIES & 17.443 .293 & 14.896 .295 & 168.293 .988 & 104.824.295 \\
\hline & IOIALEXIERINALIIIES & & 305.4 & 7.871 & \\
\hline & TOTAL PRODUCT COST $€ / \mathrm{m}^{2}$ & 13,47 & 15,67 & 16,55 & 18,93 \\
\hline & TOTAL COSTS BY CATEGORY & $309.498 .197,60$ & $212.256 .095,04$ & $3.917 .938 .069,26$ & \begin{tabular}{|l|}
$2.308 .539 .272,52$ \\
\end{tabular} \\
\hline & TOTAL & & 6.748 .2 & 31.634 & \\
\hline
\end{tabular}

The calculation of production and utilization (distribution, installation and use phases) costs of the end product, were determined per $\mathrm{m}^{2}$ and then projected on a "meso" scale on the basis of production volumes by category and total for the entire district (Table 7). The LCC analysis associated with the LCA allows translating environmental damage rates into economic damages. Every human activity consumes environmental goods (raw materials, energy, natural resources), in our case for the production of ceramic tiles, but in current practice, as well as in our case study, neither accounts nor takes care of any cost for this side effect related to these processes. This condition of use of environmental goods, not accompanied by payment for consumption, is known in economic terms as external costs or environmental externalities [84]. In this study externalities have been calculated using the Environmental Priority Strategies in Product Design (EPS2000) methodology, which is a harm-oriented approach. It considers the willingness to pay to restore the changes caused by any activity and/or process. Also in Table 7, it shows the economic valuation of externalities for each typology of ceramic product referred to each category of damage.

\subsection{LCC: Results Interpretation}

The adoption of the external costs approach allowed us to monetize the environmental impact of different ceramic tiles production. Thanks to the potential of the LCC we have been able to add to costs of manufacturing and utilization, the costs that the environmental and social system must pay for these productions. In other words, we have transformed the externalities into internal costs that can be considered in the decision-making process, reaching beyond the capital and operating costs of work. In this way it is possible to extend the limits of the perimeter of production system to the environment and territory: switching from micro to meso level.

\subsection{S-LCA: Social Assessment}

The S-LCA as well as the LCA and LCC methodologies have the same structure based on the ISO 14040 framework: the same four phases though applied to social issues. Therefore, assuming the same Goal and Scope of previous assessments, we adopted the Participatory Approach [76] of social actors involved in the management of Cultural Heritage, in order to establish and to rank the impact categories collectively. As socioeconomic indicators relevant to ceramic production in Sassuolo 
district, the expectations of the main Stakeholder have been adopted [77]. The second step of Participatory Approach, was carried out through interviews with main stakeholders including those identified in the previous phase to identify their expectations with respect to the ceramic production. The qualitative information was matched with data from the analysis of the relevant literature with the aim to prioritize the stakeholders in the next steps. The third step has been developed through multiple focuses of our research group, which represent different skills: scientific-technological and socio-economic. The fourth step was taken with the organization of a meeting between the members of our research team and the main stakeholder. The procedure of this analysis is the same as that followed by the same authors in a previous research [77]. In the fifth step, we adopted a metric approach to build a relationship between the expectations of stakeholder and the impact they have ceramic tiles manufacturers. Therefore, after the mapping of the stakeholder, we have prioritized them, in order to better design the most timely inclusion strategy. To carry out this work, the relevance of the expectations of the stakeholder are translated into a prioritization index by means of the criteria of power, urgency and proximity already described in the AA1000 standard [77].

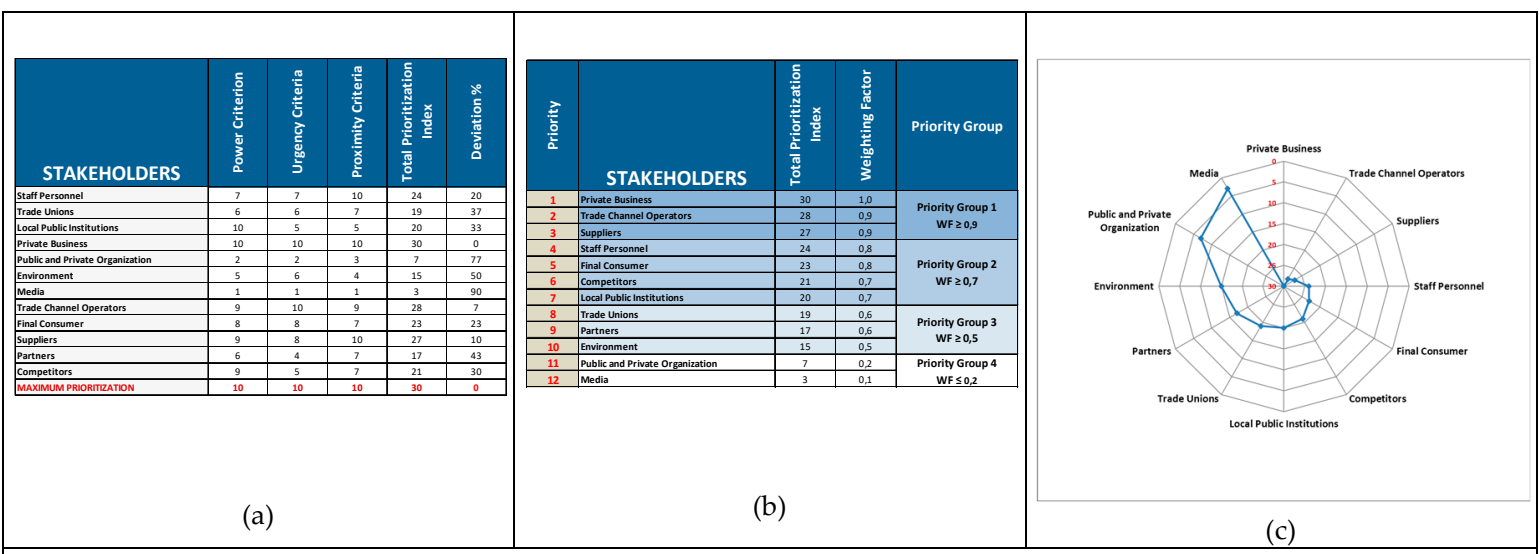

Figure 2: Scenario 1. Entrepreneurial perspective: (a) mapping, (b) prioritization and (c) graphic representation of the significance of stakeholders.

The social research applied to this case study, raised relevant methodological questions. It has been verified that the analyst's position is not neutral, when he observes social events to infer conclusions, he "interprets" social phenomena based on his background (experience, knowledge and conscience) [85]. Therefore, the research team was confronted with the intrinsic partiality of each member when collecting, processing and analyzing social data [86]. The construction of knowledge is therefore done through a continuous exchange of points of view, including those of the research team, but not only. The interpretative process and the construction of reality is also influenced by the context in which the social event occurs. Converging multiple points of view, such as stakeholder expectations, is a way to build and describe reality. Through the interpretation of these different points of view, the background of the researcher/analysts merges with those of other social agents, creating a new and more complete understanding of the reality under examination [87].

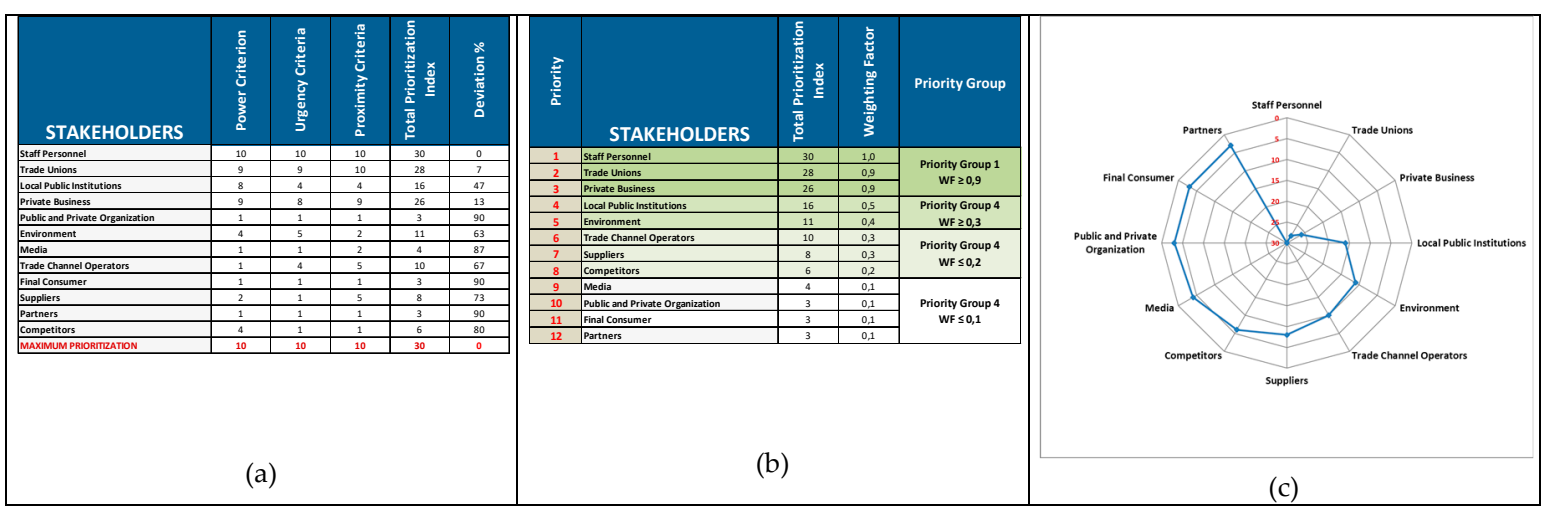


Figure 3: Scenario 2. worker's perspective: (a) mapping, (b) prioritization and (c) graphic representation of the significance of stakeholders.

For this reason, the importance of Stakeholders was declined into three sets characterized by three different perspectives of observation of reality. Scenario 1, entrepreneurial perspective (Figure 2); Scenario 2, worker's perspective (Figure 3) and Scenario 3 public institutions' perspective (Figure 4).

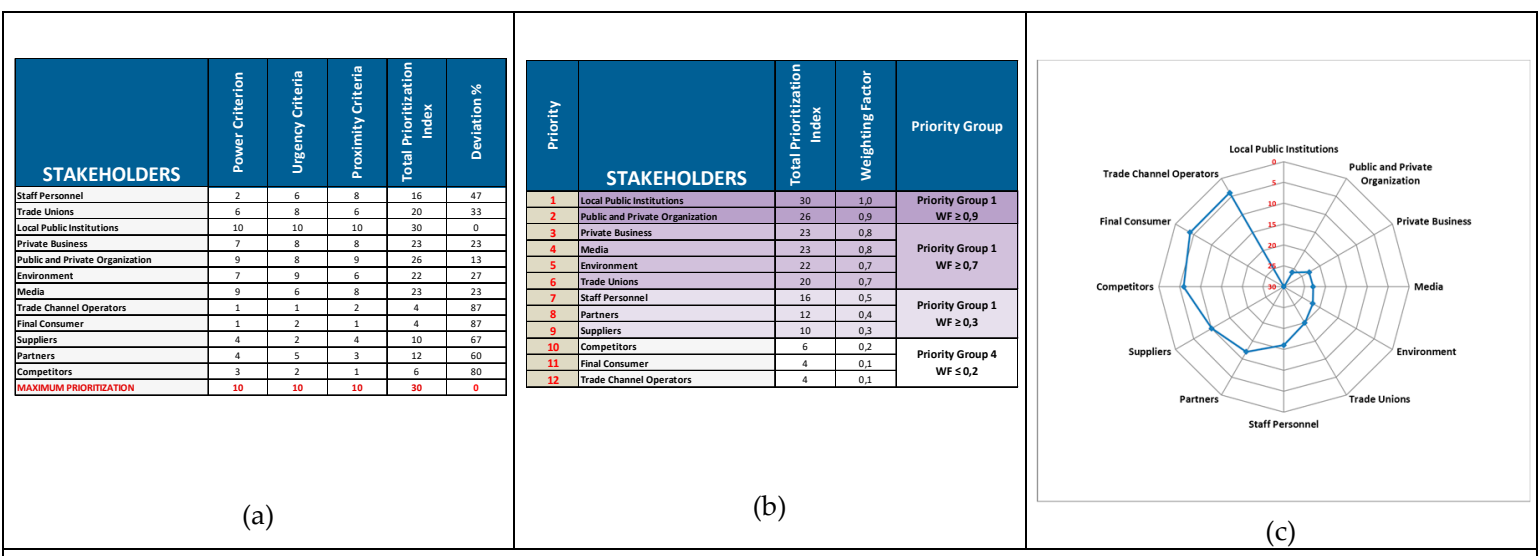

Figure 4: Scenario 3. public institutions' perspective: (a) mapping, (b) prioritization and (c) graphic representation of the significance of stakeholders.

Table "a" of each scenario considered (Figures: 2,3 and 4), shows how a priority interest rate (1 to 10) for each criterion is assigned to a stakeholder group until a total prioritization index, obtained by the sum of the partial indexes, is determined. The deviation indicates how far the total index of the maximum prioritization value goes $(30=10+10+10)$. The following Table " $\mathrm{b}$ " (Figures: 2,3 and 4) shows the list of stakeholder groups sorted by decreasing index and the corresponding weighting factor calculated by dividing the prioritization index by the maximum prioritization value. In this way each stakeholder of Sassuolo district has an index of prioritization, that is to say of relevance. As in the previous case it is possible to design a list of the stakeholders. Also for the three scenarios considered, the radial diagram of Figure "c" (Figures: 2,3 and 4), more clearly represents the relative relevance of the different stakeholders to the maximum prioritization value (to the center of the diagram).

\subsection{S-LCA: Assessment Interpretation}

By merging the different perspectives and expectations of the stakeholders of the Sassuolo ceramic district, it was possible to arrive at a new construction of the reality that has overcome the subjection of each individual economic agent or stakeholder group, as well as to reduce the problem of partiality of the members of the research team in the data collection and analysis phases. Figure 5 shows the interpretative process for the three scenarios considered: entrepreneurs, workers and public institutions. 


\begin{tabular}{|c|c|c|c|c|c|c|}
\hline \multirow[t]{2}{*}{ Priority Group } & \multicolumn{2}{|c|}{$\begin{array}{c}\text { SCENARIO } 1 \\
\text { Entrepreneurial Perspective }\end{array}$} & \multicolumn{2}{|l|}{$\begin{array}{c}\text { SCENARIO } 2 \\
\text { Worker's Perspective } \\
\end{array}$} & \multicolumn{2}{|c|}{$\begin{array}{c}\text { SCENARIO } 3 \\
\text { Public Institutions' Perspective }\end{array}$} \\
\hline & STAKEHOLDER & INDEX & STAKEHOLDER & INDEX & STAKEHOLDER & INDEX \\
\hline \multirow{3}{*}{1} & Private Business & 1,0 & Staff Personnel & 1,0 & Local Public Institutions & 1,0 \\
\hline & Trade Channel Operators & 0,9 & Trade Unions & 0,9 & Public and Private Organization & 0,9 \\
\hline & Suppliers & 0,9 & Private Business & 0,9 & & \\
\hline \multirow{4}{*}{2} & Staff Personnel & 0,8 & Local Public Institutions & 0,5 & Private Business & 0,8 \\
\hline & Final Consumer & 0,8 & Environment & 0,4 & Media & 0,8 \\
\hline & Competitors & 0,7 & & & Environment & 0,7 \\
\hline & Local Public Institutions & 0,7 & & & Trade Unions & 0,7 \\
\hline \multirow{3}{*}{3} & Trade Unions & 0,6 & Trade Channel Operators & 0,3 & Staff Personnel & 0,5 \\
\hline & Partners & 0,6 & Suppliers & 0,3 & Partners & 0,4 \\
\hline & Environment & 0,5 & Competitors & 0,2 & Suppliers & 0,3 \\
\hline \multirow{4}{*}{4} & Public and Private Organization & 0,2 & Media & 0,1 & Competitors & 0,2 \\
\hline & Media & 0,1 & Public and Private Organization & 0,1 & Final Consumer & 0,1 \\
\hline & & & Final Consumer & 0,1 & Trade Channel Operators & 0,1 \\
\hline & & & Partners & 0,1 & & \\
\hline \multicolumn{7}{|c|}{ INTERPRETATION PROCESS FOR A NEW UNDERSTANDING } \\
\hline & & 1 & Private Business & 1,0 & & \\
\hline & & 2 & Staff Personnel & 1,0 & & \\
\hline & & 3 & Local Public Institutions & 1,0 & & \\
\hline & & 4 & Trade Channel Operators & 0,9 & & \\
\hline & & 5 & Suppliers & 0,9 & & \\
\hline & & 6 & Trade Unions & 0,9 & & \\
\hline & & 7 & Public and Private Organization & 0,9 & & \\
\hline & & 8 & Final Consumer & 0,8 & & \\
\hline & & 9 & Media & 0,8 & & \\
\hline & & 10 & Competitors & 0,7 & & \\
\hline & & 11 & Environment & 0,7 & & \\
\hline & & 12 & Partners & 0,6 & & \\
\hline
\end{tabular}

Figure 5: Interpretative process of fusion of the different perspectives of entrepreneurs, workers and public institutions and construction of a new prioritization of the stakeholders of Sassuolo district.

The table above in Figure 5 represents the logic of stakeholder prioritization for each scenario. Entrepreneurs, workers and public institutions have a different construction of reality depending on the specificity of their expectations. After collecting these different visions, the research team, through a hermeneutical process [88], has carried out the fusion of the three different interpretative horizons to arrive at a new construction of reality that is represented in the table below in Figure 5 [89]. It represents a new prioritization of the stakeholders of the Sassuolo district on the basis of the perspectives of the three scenarios that have been considered. The new stakeholder list was built by combining scenarios (in columns) with priority groups (in rows) across them and listing them in descending order of priority, switching from micro to meso level. The new list of stakeholders can be the basis for defining the most appropriate strategies for engagement.

\section{Conclusions}

In this paper it was shown that the T-LCSA approach helps to incorporate the full social cost of an environmental transaction into the price of products, avoiding attributing the external costs to the community and responding to market failures. The research bridges the gap between scholars and practitioners in the field of integrating sustainability principles into business models and economic and industrial policies for the governance of territories.

In a theoretical perspective, the change of the analysis unit, from the enterprise (at micro level) to the district (at meso level), allows to take into account those externalities that would otherwise remain outside the "gates" of the economic actors and allows to transform them into sector internalities. The T-LCSA model also highlighted that the transport of raw materials is one of the most impacting factors, but above all it showed that it is not only a transaction cost (the transport from the mine to the factories), but also an environmental cost not exclusively attributable to the individual company, but to the entire sector. The determination of the monetary value of externalities has questioned the hypothesis of the "isotropicity" of space considered in terms of "pure distance", that is, that spatial element that must be filled in order to transport people with raw materials and finished products. Distance is not only transaction cost, but also environmental cost. Externalities 
have the consequence of creating situations of interdependence between subjects who are not among themselves in contractual relations. This vision raises the question of managing interactions between economic agents and internalizing externalities that cannot be left exclusively to market coordination. This is a problem of governance of the system and the implementation of appropriate economic policies aimed at attributing the cost of externalities to those who have been able to use public assets for the exercise of their economic activity. The economic quantification of external costs in aggregate terms, broadens the knowledge on the factors of pressure offering private decision makers and public administrators, useful information to prepare responses and targeted interventions of economic policies. We could therefore move from the coercive logic of "forbidding" to the positive logic of "doing better", in which the environment is no longer perceived as externality, a threat to the brake and obstacle to the development of businesses, but as an opportunity to stimulate product and process innovation.

From a managerial perspective, this experimental research has shown how the correct use of an appropriate scientific tool (the T-LCSA model) allows to quantify the economic, environmental and social impact, using process data normally available to economic agents and otherwise not always used profitably. Empirically, the study, adopting the holistic perspective of the life cycle, showed that the transport of raw materials constitutes about 20-25\% of the environmental damage produced by the entire life cycle, for all the production categories of the Sassuolo ceramic district. However, there are not great differences between the different processes of the product categories considered, in terms of environmental impact, as a demonstration of the standardization of the production phases. The process of technological standardization has also made less relevant the reduction of transaction costs related to the territorial proximity and the outsourcing of production phases and the efficiency of learning processes that are at the basis of innovation. The effects of the industrial activities of the Sassuolo district extend beyond the traditional concept of local territory to reach beyond national borders, to the countries from which the raw materials necessary to produce ceramic tiles are sourced. The social dimension of industrial activity in the district and the related costs has led us to ask ourselves about the ways in which economic actors interact and about the model of "government" of the territory. The interpretative study of the expectations of the various stakeholders, divided into three different scenarios, would evoke the creation of a district governance that guides the efforts and investments of all companies towards cost efficiency, value innovation, market presence with an adequate policy of brand, the ability to develop and integrate into international markets.

Acknowledgments: This research was funded by European Union under the LIFE Programme (LIFE16 ENV/IT/000307: LIFE Force of the Future)

Author Contributions: Anna Maria Ferrari designed and coordinated the research team, Martina Pini and Lucrezia Volpi experimentally carried out the environmental impact analyses, Cristina Siligardi conducted the technological tests on ceramic materials, Fernando E. García Muiña developed the socio-economic analysis and Davide Settembre Blundo wrote the paper.

Conflicts of Interest: The authors declare no conflict of interest. 


\section{References}

1. Anastasios Xepapadeas, A. Economic growth and the environment. In Handbook of Environmental Economics. Mäler, K.G., Vincent, J.R., Eds.; Elsevier B.V: Amsterdam, The Netherlands, 2005; Volume 3, pp. 1219-1271, ISBN 978-0-444-51146-1.

2. Jia, X., Foo, D. C., Tan, R. R., \& Li, Z. Sustainable development paths for resource-constrained process industries. Resources, Conservation and Recycling, 2017. 119, 1-3. DOI.

3. Perrings, C. Conservation of mass and instability in a dynamic economy-environment system. Journal of Environmental Economics and Management, 1986. 13(3), 199-211. DOI.

4. Dafermos, Y., Nikolaidi, M., \& Galanis, G. A stock-flow-fund ecological macroeconomic model. Ecological Economics, 2017. 131, 191-207. DOI.

5. Kharrazi, A., Kraines, S., Hoang, L., \& Yarime, M. Advancing quantification methods of sustainability: A critical examination emergy, exergy, ecological footprint, and ecological information-based approaches. Ecological Indicators. 2014, 37, 81-89. DOI.

6. Bergstrom, J. C., \& Randall, A. Natural resources, the environment, and policy. In Resource economics: an economic approach to natural resource and environmental policy, 4th Edition. Edward Elgar Publishing: Cheltenham, United Kingdom, 2016; pp. 59-74, ISBN 978-1-78471-793-3.

7. Miller, B., Soulé, M. E., \& Terborgh, J. New conservation' or surrender to development? Animal Conservation, 2014, 17(6), 509-515. DOI.

8. Neumayer, E. The human development index and sustainability-a constructive proposal. Ecological Economics, 2001, 39(1), 101-114. DOI.

9. Holden, E., Linnerud, K., \& Banister, D. The imperatives of sustainable development. Sustainable Development, 2017, 25(3), 213-226. DOI.

10. Costanza, R., Fioramonti, L., \& Kubiszewski, I. The UN Sustainable Development Goals and the dynamics of well-being. Frontiers in Ecology and the Environment, 2016, 14(2), 59-59. DOI.

11. Haas, W., Krausmann, F., Wiedenhofer, D., \& Heinz, M. How circular is the global economy?: An assessment of material flows, waste production, and recycling in the European Union and the world in 2005. Journal of Industrial Ecology, 2015, 19(5), 765-777. DOI.

12. Baldwin, J. R., Gu, W., Macdonald, R. Intangible Capital and Productivity Growth in Canada. The Canadian Productivity Review, 2012, No. 29, 6-41. DOI.

13. Maes, J., Jacobs, S. Nature-Based Solutions for Europe's Sustainable Development. Conservation Letters, 2017, 10(1), 121-124. DOI.

14. Hák, T., Janoušková, S., Moldan, B. Sustainable Development Goals: A need for relevant indicators. Ecological Indicators, 2016, 60, 565-573. DOI.

15. Corporate Social Responsibility (CSR) - European Commission. Available online: http://ec.europa.eu/growth/industry/corporate-social-responsibility en (accessed on 10 April 2018).

16. Rajeev, A., Pati, R. K., Padhi, S. S., \& Govindan, K. Evolution of sustainability in supply chain management: A literature review. Journal of Cleaner Production, 2017, 162, 299-314. DOI.

17. Waas, T., Hugé, J., Block, T., Wright, T., Benitez-Capistros, F., \& Verbruggen, A. Sustainability assessment and indicators: Tools in a decision-making strategy for sustainable development. Sustainability, 2014, 6(9), 5512-5534. DOI.

18. Mazzi, A., Toniolo, S., Catto, S., De Lorenzi, V., \& Scipioni, A. The combination of an environmental management system and life cycle assessment at the territorial level. Environmental Impact Assessment Review, 2017, 63, 59-71. DOI.

19. Peterson, E. E., Cunningham, S. A., Thomas, M., Collings, S., Bonnett, G. D., \& Harch, B. An assessment framework for measuring agroecosystem health. Ecological Indicators, 2017, 79, 265-275. DOI.

20. Iribarren, D., Martín-Gamboa, M., O’Mahony, T., \& Dufour, J. Screening of socio-economic indicators for sustainability assessment: a combined life cycle assessment and data envelopment analysis approach. The International Journal of Life Cycle Assessment, 2016, 21(2), 202-214. DOI.

21. Cosmi, C., Dvarionienė, J., Marques, I., Di Leo, S., Gecevičius, G., Gurauskienė, I., Mendes, G. \& Selada, C. A holistic approach to sustainable energy development at regional level: The RENERGY selfassessment methodology. Renewable and Sustainable Energy Reviews, 2015, 49, 693-707. DOI.

22. de Oliveira Cavalcanti, C., Limont, M., Dziedzic, M., \& Fernandes, V. Sustainability of urban mobility projects in the Curitiba metropolitan region. Land Use Policy, 2017, 60, 395-402. DOI. 
23. Dizdaroglu, D. Developing micro-level urban ecosystem indicators for sustainability assessment. Environmental Impact Assessment Review, 2015, 54, 119-124. DOI.

24. Moscatelli, S., Gamboni, M., Dernini, S., Capone, R., El Bilali, H., Bottalico, F., Debs, P. \& Cardone, G. Exploring the socio-cultural sustainability of traditional and typical agro-food products: case study of Apulia Region, South-eastern Italy. Journal of Food and Nutrition Research, 2017, 5(1), 6-14. DOI.

25. Settembre Blundo, D., Ferrari, A. M., Pini, M., Riccardi, M. P., García, J. F., \& Fernández del Hoyo, A. $\mathrm{P}$. The life cycle approach as an innovative methodology for the recovery and restoration of cultural heritage. Journal of Cultural Heritage Management and Sustainable Development, 2014, 4(2), 133-148. DOI.

26. Camuffo, A., Grandinetti, R. Italian industrial districts as cognitive systems: are they still reproducible?. Entrepreneurship \& Regional Development, 2011, 23(9-10), 815-852. DOI.

27. Sunley, P., Martin, R. A. Paul Krugman's geographical economics and its implications for regional development theory: a critical assessment. In Economy. Martin R., Ed.; 1th Edition. Routledge: London, United Kingdom, 2017; pp. 25-58, ISBN 978-1-35115-919-7

28. Phelps, N. A. External economies, agglomeration and flexible accumulation. Transactions of the Institute of British Geographers, 1992, 35-46. DOI.

29. McCann, P. Rethinking the economics of location and agglomeration. Urban Studies, 1995, 32(3), 563577. DOI.

30. Harrison, B., Kelley, M. R., \& Gant, J. Innovative firm behavior and local milieu: exploring the intersection of agglomeration, firm effects, and technological change. Economic Geography, 1996, 72(3), 233-258. DOI.

31. Asheim, B. R. T. Industrial districts as 'learning regions': a condition for prosperity. European planning studies, 1996, 4(4), 379-400. DOI.

32. Ottaviano, G. I., \& Puga, D. Agglomeration in the global economy: a survey of the 'new economic geography'. The World Economy, 1998, 21(6), 707-731. DOI.

33. Pandit, N., Cook, G., Beaverstock, J. Economies and diseconomies of clusters. In Unfolding Cluster Evolution. Belussi, F., Hervás-Oliver, J.L., Eds.; Routledge: London, United Kingdom, 2017; pp. 23-38, ISBN 978-1-31564-871-2

34. Thrift, N., Amin, A. Neo-Marshallian nodes in global networks. In Economy. Martin R., Ed.; 1th Edition. Routledge: London, United Kingdom, 2017; pp. 159-175, ISBN 978-1-35115-919-7

35. De Marchi, V., Di Maria, E., \& Gereffi, G. Industrial districts, clusters and global value chains: toward an integrated framework. In Local Clusters in Global Value Chains. De Marchi, V., Di Maria, E., Gereffi, G., Eds.; 1th Edition. Routledge: London, United Kingdom, 2017; pp. 15-132, ISBN 978-1-35172-400-5

36. Manniche, J., \& Testa, S. Towards a multi-levelled social process perspective on firm innovation: integrating micro, meso and macro concepts of knowledge creation. Industry and Innovation, 2018, 25(4), 365-388. DOI.

37. Biggeri M., Ferrannini A. Sustainable Human Development (SHD) at the Local Level. In Sustainable Human Development. 1th Edition. Palgrave Macmillan: London, United Kingdom, 2014; pp. 10-38, ISBN 978-1-137-38029-6

38. Lin, H. P., \& Hu, T. S. Knowledge interaction and spatial dynamics in industrial districts. Sustainability, 2017, 9(8), 1421. DOI.

39. Arbolino, R., De Simone, L., Carlucci, F., Yigitcanlar, T., \& Ioppolo, G. Towards a sustainable industrial ecology: implementation of a novel approach in the performance evaluation of Italian regions. Journal of Cleaner Production, 2018, 178, 220-236. DOI

40. Le Heron, R., Hayter, R. Paths of Sustainable Industrialization in the Knowledge-based Economy. In Knowledge, Industry and Environment: Institutions and Innovation in Territorial Perspective. 1th Edition. Routledge: London, United Kingdom, 2018; pp. 49-66, ISBN 978-1-35174-876-6

41. Daddi, T., Tessitore, S., \& Frey, M. Eco-innovation and competitiveness in industrial clusters. International Journal of Technology Management, 2012, 58(1/2), 49-63. DOI.

42. Hervás-Oliver, J. L., Albors-Garrigos, J., Estelles-Miguel, S., \& Boronat-Moll, C. (2017). Radical innovation in Marshallian industrial districts. Regional Studies, 2017, 1-10. DOI.

43. Hervas-Oliver, J. L., \& Davide, The case of the European ceramic tile districts in Spain and Italy. In Local Clusters in Global Value Chains. De Marchi, V., Di Maria, E., Gereffi, G., Eds.; 1th Edition. Routledge: London, United Kingdom, 2017; Chapter 10, ISBN 978-1-35172-400-5 
44. Chesbrough, H., \& Prencipe, A. Networks of innovation and modularity: a dynamic perspective. International Journal of Technology Management, 2008, 42(4), 414-425. DOI.

45. Martin, R., \& Sunley, P. Conceptualizing cluster evolution: beyond the life cycle model?. Regional Studies, 2011, 45(10), 1299-1318. DOI.

46. Trippl, M., Grillitsch, M., Isaksen, A., \& Sinozic, T. Perspectives on cluster evolution: critical review and future research issues. European planning studies, 2015, 23(10), 2028-2044. DOI.

47. Frenken, K., Cefis, E., \& Stam, E. Industrial dynamics and clusters: a survey. Regional Studies, 2015, 49(1), 10-27. DOI.

48. Carli, G., \& Morrison, A. On the evolution of the Castel Goffredo hosiery cluster: a life cycle perspective. European Planning Studies, 2018, 26(5) 915-932. DOI.

49. Ceschin, F. Critical factors for implementing and diffusing sustainable product-Service systems: insights from innovation studies and companies' experiences. Journal of Cleaner Production, 2013, 45, 7488. DOI.

50. Mathe, S. Integrating participatory approaches into social life cycle assessment: the SLCA participatory approach. The International Journal of Life Cycle Assessment, 2014, 19(8), 1506-1514. DOI.

51. Onat, N. C., Kucukvar, M., \& Tatari, O. Integrating triple bottom line input-output analysis into life cycle sustainability assessment framework: the case for US buildings. The International Journal of Life Cycle Assessment, 2014, 19(8), 1488-1505. DOI.

52. Onat, N. C., Kucukvar, M., Halog, A., \& Cloutier, S. Systems thinking for life cycle sustainability assessment: a review of recent developments, applications, and future perspectives. Sustainability, 2017, 9(5), 706. DOI.

53. Speck, R., Selke, S., Auras, R., \& Fitzsimmons, J. Life cycle assessment software: Selection can impact results. Journal of Industrial Ecology, 2016, 20(1), 18-28. DOI.

54. Ciroth, A., Hildenbrand, J., \& Steen, B. Life cycle costing. In Sustainability Assessment of Renewables-Based Products: Methods and Case Studies. Dewulf, J., De Meester, S., A.F. Alvarenga R., Eds.; John Wiley \& Sons, Ltd.: Hoboken, USA, 2016; pp.215-228. ISBN 978-1-11893-391-6

55. Petti, L., Serreli, M., \& Di Cesare, S. Systematic literature review in social life cycle assessment. The International Journal of Life Cycle Assessment, 2018, 23(3), 422-431. DOI.

56. Klöpffer, W., \& Grahl, B. From LCA to Sustainability Assessment. In Life Cycle Assessment (LCA). Klöpffer, W., \& Grahl, B., Eds. Wiley-VCH Verlag GmbH \& Co. KGaA: Weinheim, Germany, 2014; pp.357-374, ISBN 978-3-52765-562-5

57. Ferreira, F., Faria, J., Azevedo, A., \& Marques, A. L. Product lifecycle management in knowledge intensive collaborative environments: An application to automotive industry. International Journal of Information Management, 2017, 37(1), 1474-1487. DOI.

58. De Luca, A. I., Iofrida, N., Leskinen, P., Stillitano, T., Falcone, G., Strano, A., \& Gulisano, G. Life cycle tools combined with multi-criteria and participatory methods for agricultural sustainability: Insights from a systematic and critical review. Science of The Total Environment, 2017, 595, 352-370. DOI.

59. Loiseau, E., Aissani, L., Le Féon, S., Laurent, F., Cerceau, J., Sala, S., \& Roux, P. Territorial Life Cycle Assessment (LCA): What exactly is it about? A proposal towards using a common terminology and a research agenda. Journal of Cleaner Production, 2018, 176, 474-485. DOI.

60. Loiseau, E., Roux, P., Junqua, G., Maurel, P., \& Bellon-Maurel, V. Implementation of an adapted LCA framework to environmental assessment of a territory: important learning points from a French Mediterranean case study. Journal of cleaner production, 2014, 80, 17-29. DOI.

61. Loiseau, E., Roux, P., Junqua, G., Maurel, P., \& Bellon-Maurel, V. Adapting the LCA framework to environmental assessment in land planning. The International Journal of Life Cycle Assessment, 2013, 18(8), 1533-1548. DOI.

62. Dopfer, K. The origins of meso economics. Journal of Evolutionary Economics, 2012, 22(1), 133-160. DOI.

63. Chorafakis G., Laget P. Mesoeconomic Structure, Innovation and Complexity: The Concept of Mesoeconomic Plexus. In Knowledge Matters. Carayannis E.G., Formica P. Eds.; Palgrave Macmillan: London (UK), 2008; pp. 52-86. ISBN 978-0-230-58226-2

64. Gareev, T. R. Clusters in the institutional perspective: on the theory and methodology of local socioeconomic development. The Baltic region, 2012, 3(12), 4-24. DOI. 
65. Confindustria Ceramica. Environmental Product Declaration (EPD). 2016. Available online: http://www.confindustriaceramica.it/site/home/eventi/documento4981.html (accessed on 10 April 2018).

66. Confindustria Ceramica. National Statistical Survey on Italian Ceramic Tile Industry, 37th edition, 2016.

67. Alves, H. J., Melchiades, F. G., \& Boschi, A. O. Effect of spray-dried powder granulometry on the porous microstructure of polished porcelain tile. Journal of the European Ceramic Society, 2010, 30(6), 1259-1265. DOI.

68. Furferi, R., Ganugi, L., Giurgola, S., Governi, L., Puggelli, L., \& Volpe, Y. Enhancing porcelain whiteware quality assessment by means of Reverse Engineering-based procedures. Procedia Manufacturing, 2017, 11, 1659-1666. DOI.

69. Zanelli, C., Iglesias, C., Domínguez, E., Gardini, D., Raimondo, M., Guarini, G., \& Dondi, M. Mineralogical composition and particle size distribution as a key to understand the technological properties of Ukrainian ball clays. Applied Clay Science, 2015, 108, 102-110. DOI.

70. Petrick, K., Diedel, R., Peuker, M., Dieterle, M., Kuch, P., Kaden, R., \& Emmerich, K. Character and Amount of IS Mixed-layer Minerals and Physicalchemical Parameters of Two Ceramic Clays from Westerwald, Germany: Implications for Processing Properties. Clays and clay minerals, 2011, 59(1), 5874. DOI.

71. Gulsoy, O. Y., Can, N. M., Bayraktar, I., Ersayin, S., Hizal, M., \& Sahin, A. I. Two stage flotation of sodium feldspar-from laboratory to industrial application. Mineral Processing and Extractive Metallurgy, 2004, 113(3), 139-144. DOI.

72. Manfredini, T., \& Hanuskova, M. Natural raw materials in" Traditional" ceramic manufacturing. Journal of the University of Chemical Technology and Metallurgy, 2012, 47(4), 465-470. DOI.

73. ARPAE. SAD project: environmental performance indicators. Available online: https://www.arpae.it/dettaglio_generale.asp?id=1056\&idlivello=1781 (accessed on 10 April 2018).

74. Porter, M. E. The value chain and competitive advantage. In Understanding business: Barnes, D., Ed.; Routledge: London, United Kingdom, 2001; pp. 50-66, ISBN 978-0-41523-862-5.

75. Niazi, A., Dai, J. S., Balabani, S., \& Seneviratne, L. Product cost estimation: Technique classification and methodology review. Journal of manufacturing science and engineering, 2006 128(2), 563-575. DOI.

76. Mathe, S. Integrating participatory approaches into social life cycle assessment: the SLCA participatory approach. The International Journal of Life Cycle Assessment, 2014, 19(8), 1506-1514. DOI.

77. Settembre Blundo, D., Ferrari, A. M., del Hoyo, A. F., Riccardi, M. P., \& Muiña, F. E. G. Improving sustainable cultural heritage restoration work through life cycle assessment based model. Journal of Cultural Heritage. 2018, In Press. DOI.

78. AA1000 Stakeholder Engagement Standard (SES). Institute of Social and Ethical Accountability: London, United Kingdom, 2015.

79. Reynolds, M., \& Yuthas, K. Moral discourse and corporate social responsibility reporting. Journal of Business Ethics, 2008, 78(1-2), 47-64. DOI.

80. Pini, M., Ferrari, A. M., Gamberini, R., Neri, P., \& Rimini, B. Life cycle assessment of a large, thin ceramic tile with advantageous technological properties. The International Journal of Life Cycle Assessment, 2014, 19(9), 1567-1580. DOI.

81. Loiseau, E., Aissani, L., Le Féon, S., Laurent, F., Cerceau, J., Sala, S., \& Roux, P. Territorial Life Cycle Assessment (LCA): What exactly is it about? A proposal towards using a common terminology and a research agenda. Journal of Cleaner Production, 2018, 176, 474-485. DOI.

82. Weidema, B. P., Bauer, C., Hischier, R., Mutel, C., Nemecek, T., Reinhard, J., Vadenbo, C.O., Wernet, G. Overview and methodology. Data quality guideline for the Ecoinvent Database version 3. Swiss Centre for Life Cycle Inventories: Zurich, Switzerland, 2013; ID: 2389389526.

83. Sell, I., Ott, D., \& Kralisch, D. Life cycle cost analysis as decision support tool in chemical process development. ChemBioEng Reviews, 2014, 1(1), 50-56. DOI.

84. Chava, S. Environmental externalities and cost of capital. Management Science, 2014, 60(9), $2223-2247$. $\underline{\mathrm{DOI}}$.

85. Berger, R. Now I see it, now I don't: Researcher's position and reflexivity in qualitative research. Qualitative research, 2015, 15(2), 219-234. DOI. 
848

849

850

851

852

853

854

855

856

857
86. Robinson, S., \& Kerr, R. Reflexive conversations: Constructing hermeneutic designs for qualitative management research. British Journal of Management, 2015, 26(4), 777-790. DOI.

87. Gerrard, B. The significance of interpretation in economics. In Economics and Language, Henderson, W., Ed. Routledge: London, United Kingdom, 2017; pp. 51-63 ISBN 978-1-13487-322-7.

88. Gantt, E. E., Lindstrom, J. P., \& Williams, R. N. The generality of theory and the specificity of social behavior: Contrasting experimental and hermeneutic social science. Journal for the Theory of Social Behaviour, 2017, 47(2), 130-153. DOI.

89. Stenner, R., Mitchell, T., \& Palmer, S. The role of Philosophical Hermeneutics in contributing to an understanding of physiotherapy practice: a reflexive illustration. Physiotherapy, 2017, 103(3), 330-334. DOI. 